\title{
SUOMALAISEN HEVOSEN VETOVOIMAN KEHITTÄMISESTÄ
}

\author{
Mikko VARo. \\ Maatalousministeriön tuotanto-osasto.
}

Saapunut 28. V. 1947.

Oriiden vetovoiman periytymisestä.

Hevosen vetokyvyn arvioimisessa on virhetekijöiden eliminoiminen erittäin vaikeata. Vetokokeessa saatu tulos ei riipu yksinomaan siitä lihasvoimasta, minkä hevonen kykenee kehittämään, vaan mitä moninaisimmat syyt saattavat aiheuttaa mittauksessa virheellisyyksiä, joiden seurauksena hevosen vetovoimasta saadaan joko liian huono tai liian hyvä käsitys. Myös luokittelu kantakirjaanottotilaisuuksissa tulee tästä syystä helposti virheelliseksi, mikä johtaa jalostustyön hidastumiseen, jopa pysähtymiseenkin ja joka tapauksessa on omiaan vaikeuttamaan vetovoiman periytymisen toteamista. Niinpä LoNkA (1, p. 22) on orinäyttelytulosten perusteella saanut 4 -vuotiaiden isä- ja poikaoriiden vetovoimien vuorosuhteeksi vain $\mathrm{r}=+0,06 \pm 0,07 \mathrm{ja} 4$-vuotiaiden isien ja 5 -vuotiaiden poikien vuorosuhteeksi $\mathrm{r}=+0,09 \pm 0,10$. Tämä osoittaisi, jos tulosta voitaisiin pitää oikeana, että hyvien vetäjien pojat eivät olisi heikkojen poikia voimakkaampia. Toisin sanoen jalostuksella ei käytännöllisesti katsoen voitaisi hevosten vetovoimaa kehittää. Kun vetovoima kuitenkin ilmeisesti on perinnöllinen ominaisuus, LoNkA päättelee pienen vuorosuhteen johtuvan siitä, että harjoitus vetoon on epätasaista ja että vetokokeessa ei aina pyritä huipputuloksiin sekä että erilainen hoito, ruokinta ja työhön käyttö saattavat estää todellisen vetotaipumuksen esille saamisen.

Vetovoimaa ilmaisevan vetotuloksen saavuttamisessa onkin epäilemättä harjoituksella ja työhön tottumuksella tärkeä, ehkä tärkein sija. Huonosti valmennetun hevosen osoittama vetokyky ei vastaa sen todellista vetotaipumusta. Myös puutteellinen ruokinta ja hoito alentavat suorituskykyä. Lisäksi se seikka, että omistajat säästääkseen hevostaan usein tyytyvät saavutukseen, joka vetokokeen osalta turvaa pääsyn I käyttöarvoluokkaan tai jota keskimääräisiin tuloksiin nähden voidaan pitää hyvänä, on omiaan vaikuttamaan vetotuloksiin huonontavasti. Läheskään kaikki huippuluokan vetäjät eivät näin ollen erotu suuresta, keskinkertaisesta massasta. Jos näiden virhetekijöiden osuutta tuloksiin voitaisiin rajoittaa, 
päästäisiin ilmeisesti lähemmäksi todellista vetovoimaa ilmaisevia porraslukuja. Vetokokeissa saavutettuja parhaita vetotuloksia voitaisiin pitää verraten hyvin oriiden perinnöllistä vetovoimaa vastaavina, mutta erityisesti alimmissa porrasluokissa on sensijaan laadultaan hyvin erilaista hevosainesta.

Mainittuihin LoNGAn tuloksiin onkin todennäköisesti suuressa määrässä vaikuttanut häiritsevästi se, että oriiden valmennus vetokokeeseen ja työhön käyttö yleensä oli ennen vuotta 1940 varsin puutteellista. Sota-aikana toimitetut hevosotot, jotka vähensivät vetovoimaa maataloudesta, saivat kuitenkin tässä suhteessa aikaan ilmeistä korjausta, koska jäljelle jääneet hevoset oli pakko sijoittaa entistä tarkemmin töihin. Seuraus tästä näyttää käyvän ilmi myös orinäyttelyjen vetotuloksista, joiden kehitystä vuosina 1936 - 1946 seuraavat kantakirjaan hyväksyttyjen oriiden keskimääräiset porrasluvut kuvaavat:

$\begin{array}{llccc} & & 4-v . & 5-v . & 6-v . j a \text { vanh. } \\ 1936 & \ldots \ldots \ldots \ldots \ldots & 6.17 & 5.29 & 4.38 \\ 1937 & \ldots \ldots \ldots \ldots \ldots & 5.78 & 5.17 & 4.00 \\ 1938 & \ldots \ldots \ldots \ldots \ldots \ldots & 6.68 & 6.06 & 3.40 \\ 1939 & \ldots \ldots \ldots \ldots \ldots \ldots & 6.98 & 5.90 & 5.50 \\ 1940 & \ldots \ldots \ldots \ldots \ldots & 8.04 & 7.15 & 6.50 \\ 1941 & \ldots \ldots \ldots \ldots \ldots \ldots & 7.97 & 7.61 & 6.47 \\ 1942 & \ldots \ldots \ldots \ldots \ldots & 8.37 & 7.74 & 7.71 \\ 1943 & \ldots \ldots \ldots \ldots \ldots \ldots & 8.12 & 7.65 & 6.85 \\ 1944 & \ldots \ldots \ldots \ldots \ldots \ldots & 8.36 & 7.67 & 7.29 \\ 1945 & \ldots \ldots \ldots \ldots \ldots & 8.59 & 8.31 & 7.50 \\ 1946 & \ldots \ldots \ldots \ldots \ldots & 8.92 & 8.44 & 8.06\end{array}$

Sen perusteella, mitä edellä on sanottu, voidaan olettaa, että samalla kun porrasluvut ovat parantuneet, vetotulokset ovat myös lähentyneet todellista vetotaipumusta vastaavia arvoja. Tästä syystä onkin seuraavassa oriiden vetovoiman periytymistä ja siihen liittyviä seikkoja käsiteltäessä laskettu tulokset vain niiden oriiden suoritusten perusteella, joita on tarjottu kantakirjaan v. 1940 tai sen jälkeen vuoden 1946 loppuun mennessä pidetyissä näyttelyissä. Tästä aineistosta poimittujen isä-poika-parien vetosuoritusten väliset vuorosuhteet on laskettu kuitenkin vain 4-vuotiaille pareille, koska muunikäisten oriiden lukumäärä on niin pieni, että likimainkaan luotettavien tulosten saaminen niiden perusteella on täysin epävarmaa. Näin meneteltäessä aineisto jää verraten pieneksi, ja tulokset saattavat myöhemmin huomattavastikin muuttua. Kun täten saadut tulokset kaikesta huolimatta voivat kuvata tapahtunutta kehitystä ja samalla ehkä selvittää niitä suuntaviivojakin, joita noudattamalla hevosen vetovoiman arvioimisessa ja kehittämisessä voidaan päästä entistä parempiin tuloksiin, lienee aiheellista tuoda ne esiin.

Ennenkuin aineistoa ryhdytään lähemmin käsittelemään, lienee vielä syytä tarkastella paria virhetekijää, joiden vaikutus koetuloksiin saattaa joskus muodostua hyvinkin ratkaisevaksi. Nämä ovat hevosen luonne sekä eri vuodenaikojen aiheuttama koeolosuhteiden erilaisuus. Luonteen vaikutus ilmenee yleensä negatiivisena kuten edellä aikaisemmin mainittujenkin virhetekijöiden vaikutukset. Koeolosuhteet sensijaan saattavat joko huonontaa tai parantaa vetotuloksia. 
Kaikkien vuosina 1940—46 kokeiltujen oriiden jakautuminen porrasluokkiin sekä keskimääräiset vetotulokset eri vuodenaikoina käyvät ilmi taulukosta 1 .

Taulukko 1. Evi vuodenaikoina kokeiltujen oriiden jakautuminen porrasluokkiin.

Table 1. The dividing into step grades of Stallions tested at different times of the year.

\begin{tabular}{|c|c|c|c|c|c|c|c|c|c|c|c|c|c|c|c|c|}
\hline \multirow{2}{*}{$I k \ddot{a}$} & \multirow{2}{*}{$\begin{array}{c}\text { Vuodenaika } \\
\text { Season }\end{array}$} & \multicolumn{13}{|c|}{ Porrasluku - Step number } & \multirow{2}{*}{$\mathrm{n}$} & \multirow{2}{*}{ M } \\
\hline & & 1 & 1 & 2 & 3 & 4 & 5 & 6 & 7 & 8 & 9 & 10 & 11 & 12 & & \\
\hline \multirow{5}{*}{ 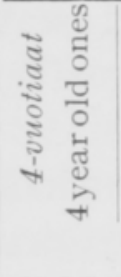 } & Talvi Winter & 11 & 2 & - & 5 & 4 & 5 & 26 & 75 & 97 & 59 & 16 & 1 & - & 301 & $7.37 \pm 0.11$ \\
\hline & Kevät Spring & 10 & - & 1 & - & 1 & 3 & 3 & 12 & 27 & 31 & 33 & 4 & 一 & 125 & $7.94 \pm 0.24$ \\
\hline & Kesä Summer & 33 & 14 & 3 & 10 & 9 & 11 & 18 & 54 & 98 & 82 & 54 & 3 & - & 389 & $7.00 \pm 0.15$ \\
\hline & Syksy Autumn & 25 & 6 & 6 & 2 & 7 & 9 & 16 & 42 & 75 & 50 & 41 & 9 & 1 & 295 & $7.12 \div 0.17$ \\
\hline & $Y h t$. In total & 79 & 22 & 10 & 17 & 21 & 28 & 63 & 189 & 297 & 222 & 144 & 17 & 1 & 1110 & $7.24 \pm 0.08$ \\
\hline \multirow{5}{*}{ 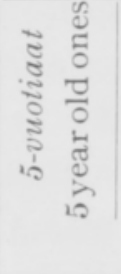 } & Talvi Winter & 28 & 4 & 3 & 5 & 6 & 22 & 64 & 79 & 78 & 27 & 7 & - & - & 323 & $6.29 \pm 0.14$ \\
\hline & Kevät Spring & 11 & 1 & 1 & - & 一 & 2 & 5 & 18 & 33 & 19 & 8 & 2 & - & 100 & $7.06 \pm 0.25$ \\
\hline & Kesä Summer & 42 & 2 & 5 & 5 & 4 & 10 & 26 & 56 & 71 & 29 & 13 & 一 & - & 263 & $6.08 \div 0.19$ \\
\hline & Syksy Autumn & 20 & 2 & 3 & 2 & 6 & 10 & 22 & 45 & 23 & 20 & 9 & 3 & - & 165 & $6.19 \pm 0.23$ \\
\hline & Yht. In total & 101 & 9 & 12 & 12 & 16 & 44 & 117 & 198 & 205 & 95 & 37 & 5 & - & 851 & $6.30 \pm 0.10$ \\
\hline \multirow{5}{*}{ 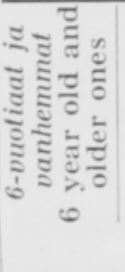 } & Talvi Winter & 19 & 1 & 5 & 5 & 8 & 40 & 50 & 55 & 23 & 10 & 3 & - & - & 219 & $5.69 \pm 0.16$ \\
\hline & Kevät Spring & 13 & 1 & 一 & - & 1 & 5 & 11 & 19 & 12 & 8 & 3 & - & - & 73 & $5.85 \pm 0.14$ \\
\hline & Kesä Summer & 38 & 3 & 2 & 9 & 11 & 14 & 32 & 35 & 20 & 7 & 3 & - & - & 174 & $4.82 \pm 0.23$ \\
\hline & Syksy Autumn & 21 & 3 & 3 & 2 & 6 & 16 & 17 & 24 & 13 & 5 & 4 & 1 & - & 113 & $5.12 \pm .029$ \\
\hline & $Y h t$. In total & 91 & 8 & 10 & 16 & 26 & 73 & 110 & 133 & 68 & 30 & 13 & 1 & - & 579 & $5.34 \pm 0.12$ \\
\hline
\end{tabular}

Eri vuodenaikoina pidetyt näyttelyt ovat vuosina 1940-1946 sattuneet seuraaviin ajankohtiin:

\begin{tabular}{|c|c|c|}
\hline talvella & & $18.1-27.2$ \\
\hline keväällä & $\ldots$ & $25.4-9.5$ \\
\hline kesällä .. & & $15.5-9.7$ \\
\hline syksyllä & & $15.8-11.10$ \\
\hline
\end{tabular}

Kevätnäyttelyitä on ollut vähän, yhteensä vain kahdeksan, ja myös kokeiltujen hevosten luku on näissä ollut pieni muiden vuodenaikojen näyttelyihın verrattuna. Ne on kuitenkin otettu eri ryhmäksi, koska kokeiluolosuhteet tähän aikaan vuodesta ovat poikkeukselliset.

Keskiarvoluvuista nähdään, että parhaat tulokset on saavutettu keväällä ja talvella, kesä- ja syksynäyttelyjen taas jäädessä tasoltaan heikommiksi. Tulos on yllättävä, sillä kesäkauden edullisemmissa olosuhteissa odottaisi päästävän suurempiin porraslukuihin. Suhde ei ilmeisesti ole sattumanvarainen, koska vaihtelu kussakin ryhmässä on hyvin samankaltainen. Tämä näkyy seuraavista suhdeluvuista:

\begin{tabular}{|c|c|c|c|c|}
\hline talvi & $\ldots \ldots \ldots$ & $\begin{array}{l}\text { 4-vuotiaat } \\
100\end{array}$ & $\begin{array}{c}\text { 5-vuotiaat } \\
100\end{array}$ & $\begin{array}{c}\text { 6-vuotiaat ja vanh. } \\
100\end{array}$ \\
\hline kevät & $\ldots \ldots \ldots \ldots \ldots$ & 108 & 112 & 103 \\
\hline kesä. & $\ldots \ldots \ldots \ldots$ & 95 & 97 & 85 \\
\hline syksy & $\ldots \ldots \ldots \ldots$ & 97 & 98 & 90 \\
\hline
\end{tabular}


Kun vaihtelu on eri ikäryhmissä näin samansuuntainen, niin huomio kiintyy lähinnä mahdollisiin koeteknillisiin virheisiin. Virheet saattavat esimerkiksi johtua joko koeauton pyörien liukumisesta, jolloin vetovastus jää tarkoitettua pienemmäksi ja porrasluku nousee todellista vetokykyä korkeammaksi, tai hevosen kavioiden liukumisesta ja lipsahtelusta, jolloin saadut tulokset antavat oriin vetokyvystä todellista heikomman kuvan, kun hevonen ei saa koko vetovoimaansa kohdistetuksi vastusmittarin jousilaitteeseen. Sen sijaan eri seutujen erilainen oriaines tuskin voi olla syynä näihin eroihin, sillä eri vuodenaikoina pidetyt näyttelyt ovat jakautuneet tasaisesti valtakunnan koko alueelle kevätnäyttelyjä lukuunottamatta, joita on pidetty vain Turussa, Lahdessa, Lappeenrannassa ja Tampereella.

Mitä näihin virhemahdollisuuksiin talvella tulee, täytyy tuloksia tällöin pitää varsin oikeina ja luotettavina, sillä tehokkaat lumiketjut estävät tällöin pyörien liukumisen täydellisesti. Myöskään kavioiden liukumista ei yleensä huolellisen kengityksen ansiosta tällöin sanottavasti tapahdu, vaikkakin hyvin jäisellä radalla jalat voivat lipsahdella jään särkyessä ja irtaantuessa kavioiden alla. Radat kuitenkin harvoin ovat siinä kunnossa, että tämä seikka voisi sanottavasti vaikuttaa tuloksiin. Kesällä, jolloin maa on kuiva ja koeradan pinta riittävän tiivis, pitäisi saatujen porraslukujen myös varsin tarkoin vastata hevosen vetokykyä kokeiluhetkenä, sillä niin kaviot kuin auton pyörätkin pureutuvat tällöin tiukasti maahan. Kun oriilla kesällä pitäisi pitemmän harjoitusajan ja suuremman työtottumuksen perusteella olla paremmat edellytykset kuin talvella hyviin suorituksiin, luulisi kesätulosten muodostuvan, päin vastoin kuin luvut näyttävät, talvisia paremmiksi. Kesä ja syksytulokset ovat 6-vuotiaiden ja sitä vanhempien ikäryhmää lukuunottamatta hyvin samaa suuruusluokkaa. Saavutusten pieni paraneminen syksyyn mennessä saattaa olla seurauksena vieläkin suuremmasta harjaantumisesta. Kuitenkin voi myös märän maan aiheuttama auton pyörien liukuminen tällöin joskus aiheuttaa virheellisyyksiä koetuloksiin. Erityisesti keväällä saattavat korkeat porrasluvut johtua märän maan pienentämistä vetovastuksista. Tosin voi jalkojen liukuminen näissä olosuhteissa osittain kumota pyörien liukumisen vaikutusta, mutta kun tarkoituksenmukainen kengitys useimmiten varmistaa kavioiden otteen maan pintaan, on lähinnä kevään ja osittain syksynkin tuloksia pidettävä virheellisen suurina. Vetokyvyn arvostelua ja siis myös sen periytymistutkimusta häiritsevänä tekijänä voidaan mainita myös se, että raskailla hevosilla niiden erittäin suurien vetovastusten vuoksi on auton liukumisen aiheuttama porraslukuja virheellisesti korottava vaikutus suurempi kuin kevyillä, joilla vuorostaan jalkojen liukuminen taas saattaa tapahtua helpommin.

Edellä esitetyn tarkastelun huomioonottaen on todennäköistä, että eri vuodenaikoina saatuihin keskimääräisiin vetotuloksiin on ollut vaikuttamassa muitakin tekijöitä kuin edellä käsitellyt koeteknilliset virheet, varsinkin kun kesä- ja syksytulosten ei todellisuudessa pitäisi olla talvisia huonompia, vaan pikemminkin hieman parempia. Tämä näennäinen ristiriita saa selityksensä tarkastettaessa oriiden jakautumista alimpiin porrasluokkiin sekä syitä tähän jakautumiseen.

Ikäryhmästä riippuen on jakautuminen $2-4$ portaalta ylöspäin verraten normaalista, mutta porrasluokkien 0 ja 1 suuri yksilöluku viittaa siihen, että veto- 
tulosten tarkempi analysoiminen on tarpeen. Vetotulos ei osoita todellista vetovoimaa, jonka syntymiselle lihasvoima ja eläinruumiin yleinen konstruktio yhdessä luovat edellytykset. Jos esitetyt monet koeolosuhteista riippuvat virheellisyydet ajateltaisiin poiseliminoiduiksi, niin tätenkään saatu vetokykyä ilmaiseva porrasluku ei vielä ole yksinomaan vetovoiman suuruudesta riippuvainen, sillä myös hevosen luonne, sen vetohalu ja rauhallisuus, vaikuttavat tulokseen. Moni hevonen voi joustavaan vastuslaitteeseen tottumattomana epäonnistua yrityksissään saada auto liikkeelle. Kuorman kimmotessa äkillisen vedon vaikutuksesta vetosuuntaan ja hevosen uudelleen ponnistaessa syntyy voimakkaita nykäyksiä, jotka asettavat vetäjän luonteen kovalle koetukselle. Hermostuminen saattaa pilata kokeen alkuunsa, mutta heikkokin rauhallinen hevonen voi vaikeasta alusta huolimatta joidenkin hukkayritysten jälkeen päästä liikkeelle. Vastuksen lisääntyessä ylemmillä portailla, mikä estää auton kimmoutumisen ja siitä johtuvat nykäykset, irtiotto varmistuu.

Verryttely- ja käyntimatkan vetovastukset ovat siksi pieniä, että karsiutuminen kokeen tässä vaiheessa ei johdu hevosen heikosta vetovoimasta, vaan lähinnä luonteesta ja harjaantumattomuudesta. Mikä hevonen tahansa kykenee voimiensa puolesta selviytymään näistä vetovastuksista, jotka iästä riippuen ovat $20-30 \%$ elopainosta, vastaten suomalaisilla hevosilla n. $90-210 \mathrm{~kg}$ :n vetovoimaa. Jos koe keskeytyy alkuportaille tai jo verryttelymatkalle yritettäessä, niin vetokykyä rajoittavana tekijänä ei tällöin ole vetovoima, vaan jo mainitut muut syyt. Tätä osoittaa sekin, että alimpiin porrasluokkiin jäävät oriit eivät pääse vedossaan lainkaan alkuun, mutta ylemmissä portaissa koe sensijaan päättyy auton pysähtyessä vetäjän voimien loppuessa vetotaipaleelle. Hevosen vetovoiman periytymistä tutkittaessa ei hevosen kokeessa osoittamaa vetokykyä voida sen vuoksi pitää lähtökohtana, vaan on koetettava löytää ne vetokyvyn arvot, jotka mahdollisimman tarkoin vastaavat yksinomaan vetovoimaa. Missä luonteen ja harjaantumattomuuden ja toisaalta vetovoiman loppumisen aiheuttaman karsinnan raja kulkee, on mahdotonta tarkalleen määrätä, sillä todennäköisimmin edellisten vaikutus hitaasti vähenee vetovoiman alkaessa 4-6 portaalta lähtien yhä ratkaisevammin määrätä vetokyvyn suuruutta. Mitä korkeampiin portaisiin päästään, sitä oikeamman kuvan hevosen vetovoimasta tulos antaa. Jättämällä laskuista pois ne oriit, joiden karsiutumiseen todennäköisimmin pelkästään muut syyt kuin voiman loppuminen on ollut syynä, voidaan odottaa oikeampia lopputuloksia, joskaan virhettä ei näinkään kokonaisuudessaan kyetä välttämään. Seuraavissa laskutoimituksissa on rajaksi valittu $35 \%$ :n vetovastus, jolloin 4 -vuotiaiden ryhmässä jäävät pois $0-2$ porrasluokat, 5-vuotiaissa $0-1$ ja vanhimpien ikäryhmässä 0 -luokka. Tätä voidaan perustella sillä, että eri-ikäisten oriiden erilaiset vetotulokset mahdollisesti johtuvat pääasiassa niille asetetuista erilaisista vetovaatimuksista (3), minkä vuoksi myös niiden ryhmittyminen alimpiin porrasluokkiin on ollut jossakin määrin erilaista.

Laskemalla eri vuodenaikoina saavutetut keskimääräiset vetotulokset vähintään $35 \%$ elopainostaan vetäneiden oriiden porraslukujen perusteella on eri ikäryhmille saatu seuraavat absoluuttiset ja suhteelliset keskiarvot: 


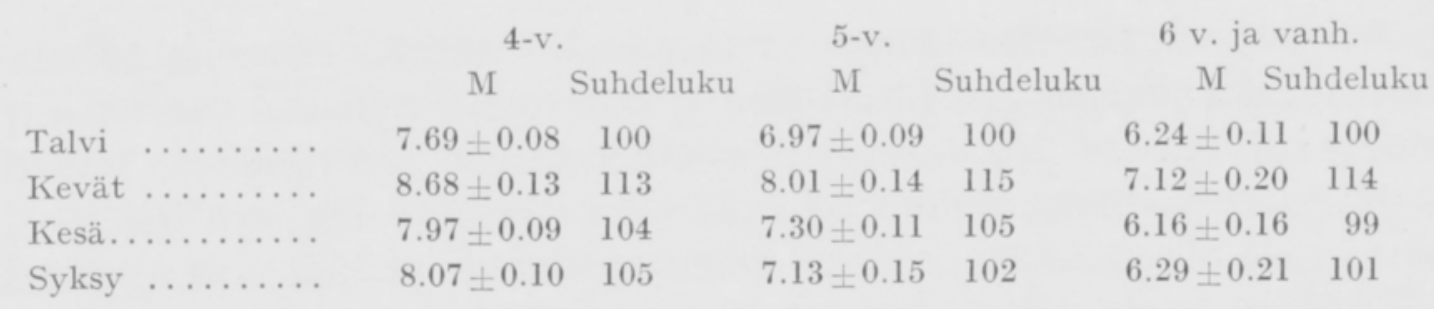

Näistä vähintään $35 \%$ elopainostaan vetäneiden oriiden porraslukujen keskiarvoista havaitaan, että talvi- ja kesäkauden näyttelyjen tulostasojen suhde on nyt muuttunut sellaiseksi kuin sen odottaisikin muodostuvan. Kevätnäyttelyjen porrasluvut ovat selvästi muita paremmat ja edellä esitetyt seikat huomioonottaen todennäköisesti virheellisen korkeat. Muina vuodenaikoina tulokset ovat verraten samanarvoisia, joskin nuorimmissa ikäryhmissä on havaittavissa jonkin verran eroavaisuutta. Tämäkin viittaa siihen, että luvut nyt kuvastavat paremmin kuin korjaamattomina todellista vetovoimaa, koska hevosen iän lisääntyessä myös tottumus työhön kasvaa ja kokeiluajan myöhempään vuodenaikaan siirtymisen merkitys vähenee.

Vetovoiman periytyminen isältä pojalle.

Taulukossa 2 on esitetty kaikkien 4 -vuotiaiden isä- ja poikaparien vetotulokset porraslukuina ilmaistuina. Ne osoittavat, että vetokykyjen vuorosuhde on aikaisemmin esitettyihin tutkimustuloksiin verrattuna ehkä jonkin verran selvempi, joskin tässäkin epävarma. Edellä tehty olettamus, että vetotulokset ovat parantuessaan lähestyneet todellista vetovoimaa vastaavia arvoja, on ilmeisesti ollut oikea. Kehitys ei kuitenkaan vielä ole johtanut aikaisemmin mainittujen vetovoiman mittaamista häiritsevien virhetekijöiden häviämiseen tai edes riittävään heikkenemiseen. Tehostetulla harjoituksella voitaisiin epäilemättä edelleenkin lisätä tulosten tarkkuutta.

Taulukko 2. 4-vuotiaiden isien ja poikien vetokykyjen vuorosuhde.

Table 2. The correlation of the pulling ability of 4 year old sires and sons.

\begin{tabular}{|c|c|c|c|c|c|c|c|c|c|c|c|c|c|c|c|}
\hline \multirow{9}{*}{ 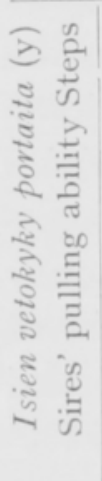 } & \multicolumn{15}{|c|}{ Poikien vetokyky portaita $(\mathrm{x})$ Sons' pulling ability steps } \\
\hline & & 0 & 1 & 2 & 3 & 4 & 5 & 6 & 7 & 8 & 9 & 10 & 11 & $\mathrm{n}$ & M \\
\hline & 6 & 1 & & & & & & 1 & & & & & & 2 & 3.00 \\
\hline & 7 & & & & & & & 2 & & 1 & 3 & & & 6 & 7.83 \\
\hline & 8 & 2 & 1 & & & & & 1 & 6 & 15 & 11 & 13 & 1 & 50 & 8.18 \\
\hline & 9 & & & 1 & 1 & & & & 3 & 3 & 4 & 3 & 1 & 16 & 7.94 \\
\hline & 10 & 1 & & & & & & & & 3 & 3 & 4 & 1 & 12 & 8.50 \\
\hline & $\mathrm{n}$ & 4 & 1 & 1 & 1 & & & 4 & 9 & 22 & 21 & 20 & 3 & 86 & 8.04 \\
\hline & $\mathrm{M}$ & 8.00 & 8.00 & 9.00 & 9.00 & & & 7.00 & 8.33 & 8.36 & 8.33 & 8.55 & 9.00 & 8.35 & \\
\hline & & & & $\begin{array}{l}\mathrm{M} \\
\mathrm{M}\end{array}$ & $\begin{array}{l}x=8 \\
y=8\end{array}$ & $\begin{array}{l}4 \pm \\
35 \pm\end{array}$ & & $7 \pm 0$ & $\begin{array}{l}x= \\
y=\end{array}$ & $\begin{array}{l} \pm 2.47 \\
\pm 0.89\end{array}$ & & & & & \\
\hline
\end{tabular}


Taulukko 3. 4-vuotiaiden isien ja poikien, joiden emien vetovarmuus on 6 p., vetokykyjen vuorosuhde. Table 3 . The pulling ability's correlation of 4 year old sires and sons, whose dams pulling reliability is 6 p.

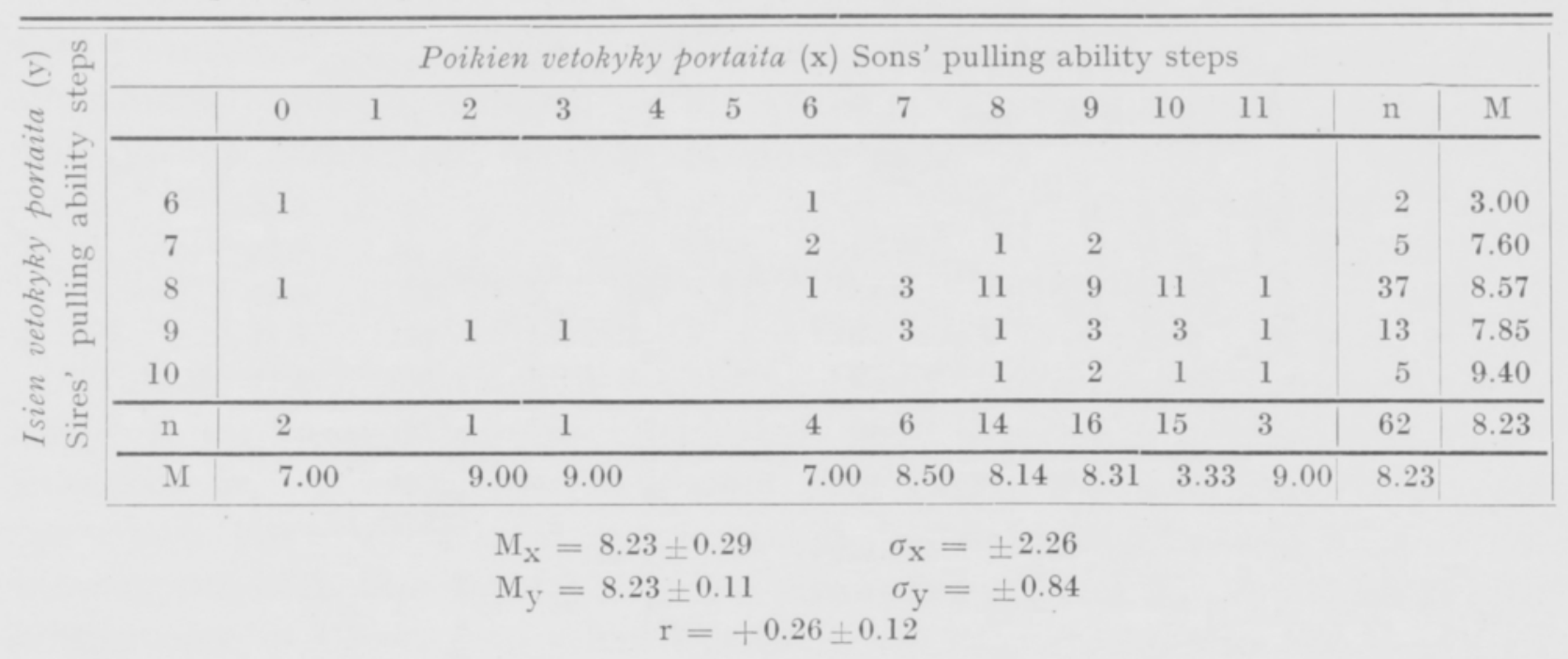

Jos vertailtavien oriparien lukumäärä olisi hyvin suuri, ei tammojen perinnöllistä vaikutusta poikiensa perinnölliseen vetovoimaan olisi vuorosuhdelaskelmassa lainkaan tarpeellista ottaa huomioon, koska vetokyvyltään eriarvoiset oriit joutuisivat todennäköisesti astumaan hyvin erilaisia tammoja ja poikaoriiden emäaines muodostuisi näin ollen varsin tasalaatuiseksi. Tähän viittaavat mm. VAINIKAISEN (2, p. 74) suorittamat tutkimukset, jotka osoittavat, etteivät vetokyvyltään parempien oriiden astumat tammat ole olleet keskimäärin sen parempia vetovarmuudeltaan kuin heikompienkaan oriiden astumat. Sen sijaan pienessä aineistossa, mistä tässä on kysymys, saattaa tammojen vaikutus isien eri porrasluokissa muodostua hyvin erilaiseksi. Tästä syystä on taulukossa 3 laskettu erikseen vuorosuhde vain niiden parien perusteella, joiden poikien emien vetovarmuus on arvosteltu 6 pisteeksi. Täten valittu homogeenisempi tamma-aines häiritsee epäilemättä vähemmän isien ja poikien vetokyvyn keskinäistä riippuvaisuutta. Tulos osoittaakin, että päätelmä on ilmeisesti oikea, sillä täten saatu vuorosuhde $r=+0,26 \pm 0.12$ on jo selvä, joskin matemaattisesti epävarma.

Taulukoista 1 ja 2 ilmenee myös, että isien jakautuminen porrasluokkiin on ollut jotenkin normaalista. Alimpien porrasluokkien pieni yksilöluku johtunee siitä, että näihin kuuluvia oriita on hyväksytty kantakirjaan suhteellisen vähän, ja kantakirjaan hyväksymättömien siitokseen käyttö on taas ollut perin harvinaista; ainakin on niiden jälkeläisten kantakirjaan tarjonta ollut muihin verrattuna häviävän pientä. Poikien jakaantuminen poikkeaa sensijaan selvästi ns. normaalisesta jakautumisesta alimpien porrasluokkien yksilöiden muodostaessa oman erillisen ryhmänsä. Näiden sijoittuminen alimmille portaille ei ilmeisesti johdukaan heikosta vetovoimasta, vaan niinkuin edellä on esitetty, harjaannuksen puute ja luonneviat ovat olleet todellisen vetokyvyn esille saamisen esteenä. Kokeessa epäonnistuneet yksilöt, jotka muodostavat erillisen ryhmän, voidaan sen vuoksi jättää laskelmista pois, jolloin saatava vuorosuhde paremmin kuvastaa isien ja poikien lihasvoimaan ja ruumiin konstruktioon perustuvaa vetokykyä, vetovoimaa. Näin menetellen korjautuvat taulukon 2 tulokset sellaisiksi kuin ne ovat taulukossa 4. 
Taulukko 4. 4-vuotiaiden isien ja poikien vetovoimien vuorosuhde. Table 4. The correlation of the pulling power of 4 year old sires and sons.

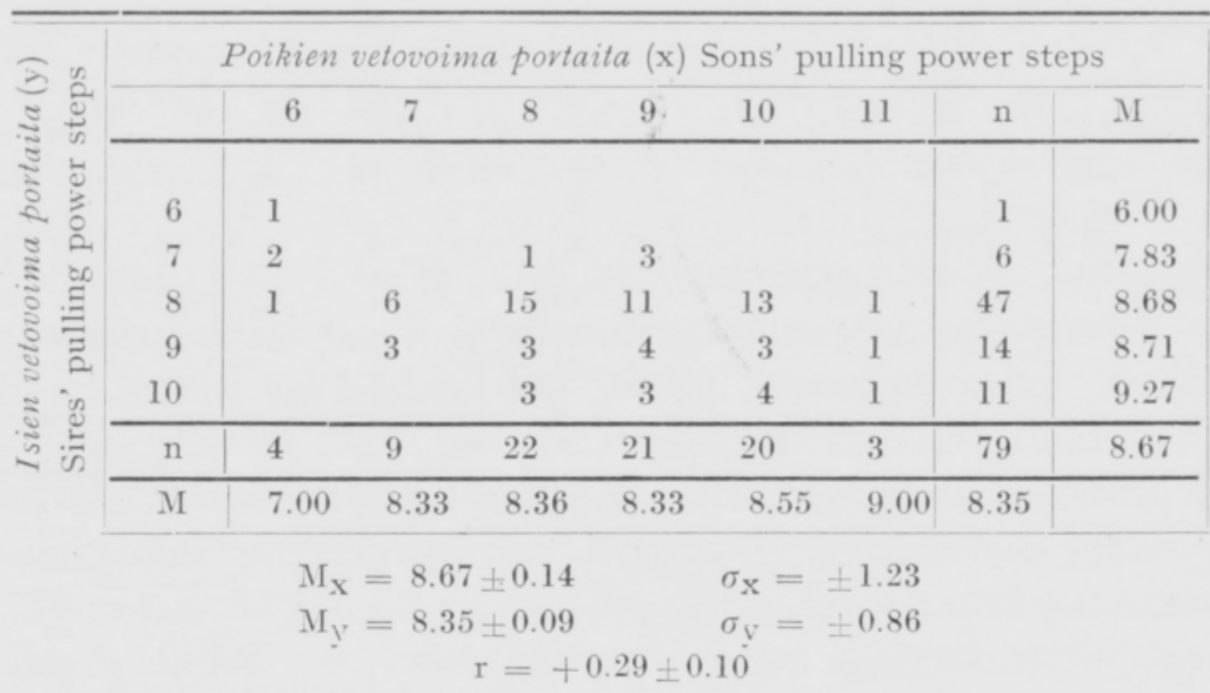

Taulukosta 4 nähdään, että isien porraslukujen noustessa poikienkin vetotulosten keskiarvot ovat kohonneet, joskin alemmissa porrasluokissa jyrkemmin kuin ylemmissä. Vuorosuhde $+0.29 \pm 0.10$ osoittaa, että voimakkaat oriit jättävät pääasiassa voimakkaita jälkeläisiä. Jotta tammakannan heterogeenisuuden vaikutusta tässäkin voitaisiin vähentää, on poikaoriiden alimpien porrasluokkien poisjättämisellä korjatut tulokset esitetty myös taulukon 3 aineistosta, jossa ovat mukana vain kaikki 6 pisteen tammojen pojat. Näin saatu vuorosuhde on laskettu taulukossa 5.

Taulukko 5. 4-vuotiaiden isien ja poikien, joiden emien vetovarmuus on 6 p., vetovoimien vuorosuhde Table 5. The pulling power's correlation of 4 year old sires and sons, whose dams pulling reliability is $6 \mathrm{p}$

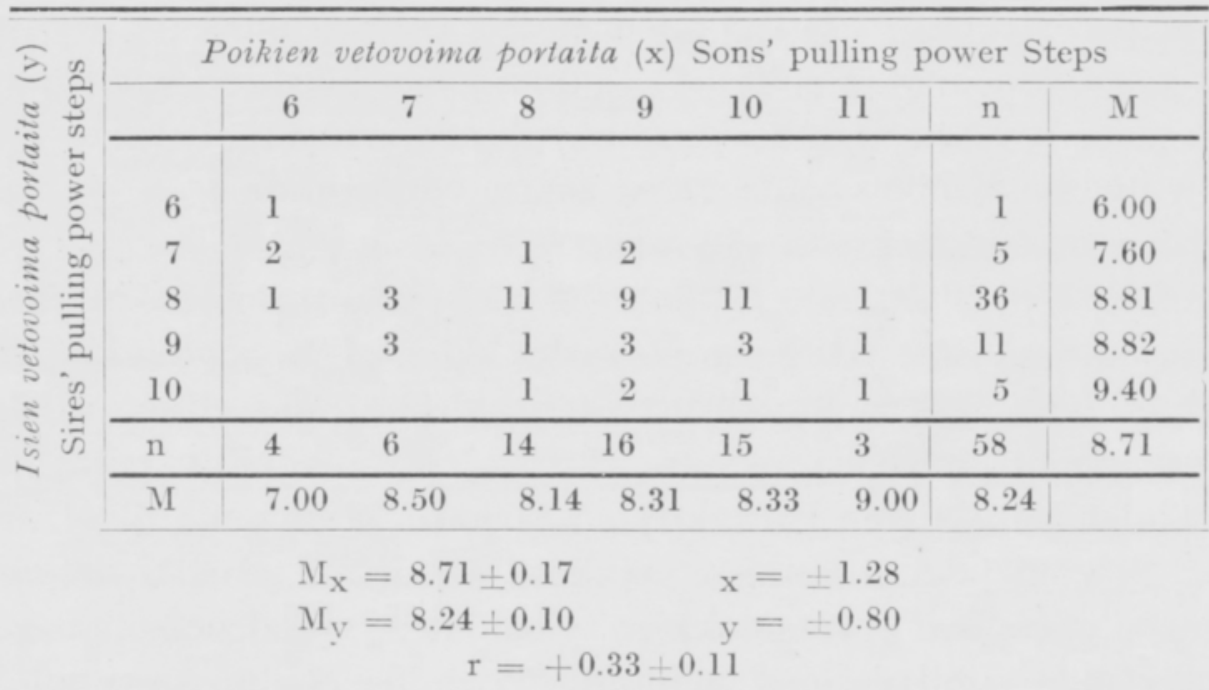

Kaikissa edellä selostetuissa laskelmissa on eräänä lopputulokseen epäedullisesti vaikuttavana tekijänä mainittava se, että isäoriiden jakautumisen sekä sen perusteella lasketun keskiarvon määräävät ensisijassa ne oriit, joilla on useita poikia. Jos vuorosuhteet lasketaan kunkin isän poikien keskimääräisten porraslukujen perusteella, jolloin jokainen isäori esiintyy vain kerran korrelaatiotaulussa, 
saadaan vuorosuhdekertoimen arvoiksi taulukon 4 aineistolle $\mathrm{r}=+0.37 \pm 0.15$ ja taulukon 5 aineistolle $r=+0.46 \pm 0.15$. Käsiteltävä aineisto näyttää tällöin entistä pienemmältä ja tulosten luotettavuus saattaakin tästä kärsiä, mutta tämän menetelmän voidaan sittenkin katsoa paremmin kuvastavan isien vetovoiman periytymistä jälkeläisjoukolle kokonaisuudessaan.

\section{Tammojen vaikutus poikien vetovoimaan.}

Taulukoiden 3 ja 5 tulokset osoittavat jo, että vetovarmuudeltaan hyvät tammat ovat ilmeisesti vaikuttaneet edullisesti poikien vetosaavutuksiin, sillä niiden aineistoon sisältyvien poikien keskiarvot ovat kaikkien poikaoriiden keskiarvoja paremmat. Myös verrattaessa isien ja poikien keskimääräisiä tuloksia toisiinsa havaitaan, että kaikki tammat käsittävässä aineistossa (talukot 2 ja 4) poikien ja isien keskiarvojen erotukset ovat olleet -0.31 ja +0.32 porrasta, kun taas 6 pisteen tammojen poikien vetotulokset (talukot 3 ja 5 ) ovat poikenneet \pm 0.00 ja +0.47 porrasta isiensä vetotuloksista. Taulukossa 6 esitetään tarkemmin poikien keskiarvojen eroavaisuudet isien porrasluvuista, mitkä ovat saattaneet johtua tammojen erilaisesta perinnöllisestä vetovoimasta. Aineisto käsittää vain sen oriaineksen, josta on karsittu pois harjoituksen puutteessa ja luonnevikojen vuoksi vetokokeessa epäonnistuneet poikaoriit, jotta tulokset mahdollisimman tarkoin vastaisivat yksinomaan vetovoimasta riippuvia vetotuloksia.

Taulukko 6. Poikien vetotulosten eroavaisuus isien vetotuloksista.

Table 6. The sons' pulling results deviations from the sires pulling results.

\begin{tabular}{|c|c|c|c|c|c|c|c|c|}
\hline \multirow[t]{2}{*}{$\begin{array}{c}\text { Isien porrasluku } \\
\text { The sires' step } \\
\text { number }\end{array}$} & \multicolumn{2}{|c|}{$\begin{array}{l}\text { Kaikkien emien } \\
\text { pojat } \\
\text { The sons of all } \\
\text { dams }\end{array}$} & \multicolumn{2}{|c|}{$\begin{array}{c}6 \text { p. emien pojat } \\
\text { The sons of } 6 \mathrm{p} . \\
\text { dams }\end{array}$} & \multicolumn{2}{|c|}{$\begin{array}{l}5 \text { p. emien pojat } \\
\text { The sons of } 5 \mathrm{p} . \\
\text { dams }\end{array}$} & \multicolumn{2}{|c|}{$\begin{array}{l}o-4 \text { p. emien } \\
\text { pojat } \\
\text { The sons of } 0-4 \\
\text { p. dams }\end{array}$} \\
\hline & $\mathrm{n}$ & $\begin{array}{c}\text { ero } \\
\text { deviation }\end{array}$ & $\mathrm{n}$ & $\begin{array}{c}\text { ero } \\
\text { deviation }\end{array}$ & $n$ & $\begin{array}{c}\text { ero } \\
\text { deviation }\end{array}$ & $\mathrm{n}$ & $\begin{array}{c}\text { ero } \\
\text { deviation }\end{array}$ \\
\hline 6 & 1 & 0 & 1 & 0 & - & & - & \\
\hline 7 & 6 & +0.83 & 5 & +0.60 & - & & 1 & +2.00 \\
\hline 8 & 47 & +0.68 & 36 & +0.81 & 4 & +1.0 & 7 & -0.14 \\
\hline 9 & 14 & -0.29 & 11 & -0.18 & 1 & -1.0 & 2 & -0.50 \\
\hline \multirow[t]{2}{*}{10} & 11 & -0.73 & 5 & -0.60 & 3 & -1.0 & 3 & -0.67 \\
\hline & 79 & +0.32 & 58 & +0.78 & 8 & \pm 0.0 & 13 & -0.15 \\
\hline
\end{tabular}

Taulukon 6 luvut osoittavat, että poikien vetotulosten keskiarvot ovat poikenneet isien tuloksista alemmissa porrasluokissa positiiviseen ja ylemmissä negatiiviseen suuntaan. Positiiviset poikkeamat johtuvat luonnollisesti osittain siitä aikaisemmin mainitusta seikasta, että alimpien porrasluokkien isäoriiden joukossa on yksilöitä, jotka paremmalla harjoituksella olisivat päässeet korkeampaan vetotulokseen ja jotka ovat periyttäneet mukautuman peittämän hyvän vetovoimansa paremmin koulutetuilla jälkeläisilleen. Osittain on syynä poikkeamiin kuitenkin 
täytynyt olla tammojen isäoriita paremman vetokyvyn, sillä harjaantumattomuus yksinään tuskin aiheuttaisi näin suurta vähenemistä todellisen vetovoiman edellyttämistä arvoista. Tätä käsitystä tukee se seikka, että jos vähintään $35 \%$ elopainostaan vetäneistä 4-vuotiaista oletettaisiin kaikkien $3-6$ portaalle jääneiden oriiden karsiutuneen muista syistä kuin vetovoiman vähäisyyden vuoksi, olisi näiden negatiivinen vaikutus keskimääräisiin vetotuloksiin ollut 0,43 porrasta, ja jos vielä 7 portaan vetäjätkin luettaisiin mainittuun joukkoon, olisi niiden aiheuttama väheneminen 0.83 porrasta. Kun puheena olevien porrasluokkien yksilöistä kuitenkin todennökäisesti melkoinen osa on ollut todella heikkoa vetäjäainesta, on uskottavaa, että taulukossa 6 esitetyissä 7 ja 8 portaan oriiden ja niiden poikien vetotulosten eroissa on näkyvissä myös emäin puolelta saatua vaikutusta. Korkeampien porrasluokkien negatiivisia poikkeamia voidaan sensijaan tuskin laisinkaan selittää muiden syiden kuin tammojen aiheuttamaksi. Tämän kaltainen tammojen poikiensa vetotuloksia tasoittava vaikutus on luonnollinen, sillä tammat, ja varsinkin ne, joiden vetovarmuus on arvosteltu 6 pisteeksi, ovat luultavasti vetovoimaltaan likimain keskinkertaisten oriiden tasolla. Tammojen kantakirjakokeiden vetovaatimukset ovat toistaiseksi minimivaatimuksia, jotka kylläkin karsivat pois erikoisen heikon aineksen, mutta jotka eivät riitä erottamaan huippuyksilöitä tyydyttäväntasoisesta massasta, minkä juuri 6 pisteen tammat muodostavat. Nykyinenkään karsinta ei kuitenkaan ole merkityksetön. Tämän positiivista vaikutusta tammakannan käyttöarvoon osoittavat taulukossa 6 esitetyt eriarvoisten tammojen poikiensa tuloksiin aiheuttamat keskimääräiset poikkeamat isien porrasluvuista. Pisteluokkiin $0-4$ kuuluvat emät, joihin luetaan myös sekä kantakirjattomat että vanhat kokeilemattomat tammat, ovat alentaneet jälkeläistensä vetovoimaa, mutta 6 pisteen emät sensijaan ovat edistäneet jalostustyötä. Poikkeamat eivät kuitenkaan kuvaa sitä absoluuttista määrää, millä tammat ovat lisänneet tai vähentäneet poikien vetovoimaa, koska monet muut aikaisemmin selostetut tekijät ovat olleet mukana vaikuttamassa tulostason jatkuvaan nousuun niin, että pojat ovat olleet vetokyvyltään isiään parempia, mutta ne osoittavat kuitenkin tammojen luokittelun suhteellista arvoa. Emien epäedullinen vaikutus parhaiden oriiden jälkeläisiin puolestaan osoittaa, kuinka tarpeellista olisi kehittää myös tammojen vetovoiman kokeilu sellaiseksi, että luokittelu muodostuisi yhtä tehokkaaksi kuin oriillakin, sillä vain täten voidaan jalostustyössä päästä nopeasti ja varmasti tuloksiin.

\section{Poikaoriiden vetotulokset keskiporraslukuihin verrattuna.}

Jotta nähtäisiin, voidaanko hyvien vetäjien siitokseen käytöllä parantaa hevoskannan keskimääräistä vetovoimaa, on 8 ja useampia portaita vetäneiden oriiden poikien vetotuloksia verrattu kaikkien kokeiltujen oriiden porraslukujen keskiarvoihin. Kun myös ennen vuotta 1940 vetokokeesta hyvin selviytyneiden oriiden saavutuksia voidaan pitää vetovoimaa tyydyttävästi kuvaavina, laskelmiin on aineiston lisäämiseksi otettu mukaan kaikkien vuodesta 1936 lähtien vähintään 8 porrasta vetäneiden oriiden pojat, lukuunottamatta kuitenkaan 5-vuotiaiden isien poikia, joita on ollut vain 13, ja 4-vuotiaiden isien 6-vuotiaita poikia, joita 
Taulukko 7. Porraskeskiarvojen kehitys vuosina 1940-1946.

Table 7. The evolution of the averages of steps numbers in $1940-1946$.

\begin{tabular}{|c|c|c|c|c|c|c|}
\hline \multirow[t]{2}{*}{ Vuosi - Year } & \multicolumn{3}{|c|}{ Kaikki oriit - All Stallions } & \multicolumn{3}{|c|}{$\begin{array}{c}\text { Vähint. } 35 \% \text { elopainostaan vetäneet oritt } \\
\text { Sons who have pulled at least } 35 \% \text { of } \\
\text { their live weight }\end{array}$} \\
\hline & 4-v. & 5 -v. & 6-v. ja vanh. & $4-v$. & 5 -v. & 6-v. ja vanh. \\
\hline 1940 & 6.86 & 5.06 & 3.88 & 7.92 & 6.55 & 5.61 \\
\hline 1941 & 6.80 & 6.11 & 4.53 & 7.39 & 7.02 & 5.86 \\
\hline 1942 & 6.76 & 6.24 & 5.15 & 7.81 & 7.10 & 6.03 \\
\hline 1943 & 6.63 & 6.05 & 5.50 & 7.40 & 6.98 & 6.22 \\
\hline 1944 & 7.38 & 6.13 & 5.23 & 8.02 & 6.88 & 6.15 \\
\hline 1945 & 7.46 & 6.51 & 5.35 & 8.30 & 7.55 & 6.19 \\
\hline 1946 & 8.08 & 7.34 & 6.06 & 8.68 & 7.98 & 7.25 \\
\hline
\end{tabular}

on ollut vain 3. Alkuvuosien pienen yksilöluvun vuoksi ei poikaoriita ole ryhmitelty vuosiluokkiin, sillä esimerkiksi 4-vuotiaista pojista on $69,7 \%$ kokeiltu vuonna 1946 , vaan vetokyvyltään erilaisten isien poikien vetotuloksia on verrattu vuoden 1946 keskiarvoihin, jotka ovat korkeimmat siihen mennessä saavutetuista. Taulukko 7 näyttää kaikkien kokeiltujen oriiden keskitulosten kehityksen vuodesta 1940 lähtien, ja taulukosta 8 nähdään edellä esitetyn vertailun tulos.

Niinkuin aikaisemmin esitettyjen vuorosuhteiden pienuuden perusteella voi odottaakin, eroavat erilaisten isien pojat varraten vähän toisistaan, mutta ylittävät parhaiden vetäjien jälkeläiset selvimmin keskitason. Sensijaan 8 porrasta vetäneet oriit ovat jättäneet vetokyvyltään vain keskinkertaisia jälkeläisiä.

Edellä on jo mainittu siitä, että tehokkaampi työhön käyttö sota-aikana vaikutti edullisesti oriiden vetotuloksiin. Taulukon 7 luvut osoittavat, että rauhantilan palattua on alkanut uusi voimakas kehitys korkeampiin porraslukuihin, mikä epäilemättä on pantava miesväen kotiutumisen ja vasta nyt alkaneen oriiden perusteellisemman valmennuksen ansioksi. Keskitaso on kohonnut siinä määrin, ettei 8 portaan saavutus enää ilmeisesti osoita mitään poikkeuksellisia vetäjän lahjoja. Kantakirjavaatimuksia tarkistamalla olisi sen vuoksi kiireesti päästävä siihen, että

Taulukko 8. Vetokyvyltään erilaisten oriiden poikien vetotulokset vuoden 1946 keskiarvoihin verrattuna. Table 8. The pulling results of sons of sires with dissimilar pulling ability compared to averages ot 1946.

\begin{tabular}{|c|c|c|c|c|c|c|c|c|c|c|}
\hline & \multirow{3}{*}{$\begin{array}{c}\text { Isien } \\
\text { porras- } \\
\text { luku } \\
\text { The } \\
\text { sires' } \\
\text { step } \\
\text { number }\end{array}$} & \multirow{2}{*}{\multicolumn{3}{|c|}{$\begin{array}{l}\text { Kaikki pojat } \\
\text { All sons }\end{array}$}} & \multicolumn{6}{|c|}{$\begin{array}{c}\text { Vähintäin } 35 \% \text { elopainostaan vetäneet pojat } \\
\text { Sons who have pulled at least } 35 \% \text { ot their } \\
\text { live weight }\end{array}$} \\
\hline & & & & & \multicolumn{3}{|c|}{ Kaikki - All } & \multicolumn{3}{|c|}{$\begin{array}{l}6 \text { p. emien pojat } \\
\text { The sons of } 6 \mathrm{p} \text {. dams }\end{array}$} \\
\hline & & $\mathrm{n}$ & M & $\begin{array}{c}1946 \\
=100 \\
\end{array}$ & $\mathrm{n}$ & M & $\begin{array}{l}1946 \\
=100 \\
\end{array}$ & $\mathrm{n}$ & M & $\begin{array}{l}1946 \\
=100 \\
\end{array}$ \\
\hline 4-v. isät ja 4-v. pojat & 8 & 77 & $8.01 \pm 0.27$ & 99 & 72 & $8.53 \pm 0.17$ & 98 & 52 & $8.79 \pm 0.15$ & 101 \\
\hline 4 year old sires and & 9 & 20 & $8.25 \pm 0.46$ & 102 & 18 & $8.89 \pm 0.20$ & 102 & 14 & $9.00 \pm 0.36$ & 104 \\
\hline 4 year old sons & 10 & 12 & $8.50 \pm 0.82$ & 105 & 11 & $9.27 \pm 0.30$ & 107 & 5 & $9.40 \pm 0.52$ & 108 \\
\hline
\end{tabular}


kantakirjaoriit edustaisivat laadultaan keskitasoa selvästi parempaa hevosainesta. Vuonna 1946 hyväksyttyjen työhevoskantakirjaoriiden keskimääräiset vetotulokset olivat 4 -vuotiailla $8.83,5$-vuotiailla 8.36 ja 6 -vuotiailla ja sitä vanhemmilla 8.00 porrasta, eli vastaavasti vain $0.15,0.38$ ja 0.75 porrasta kaikkien kokeiltujen oriiden keskituloksista korkeammat. Kun lisäksi siitokseen käyttö ehkä hyvinkin vähässä määrin keskittyy vetokyvyltään parhaisiin hevosiin, jää varsinkin 4-vuotiaina hyväksyttyjen oriiden, joita on ollut keskimäärin $55.1 \%$ kaikista kantakirjaoriista, jalostuksellinen vaikutus vähäiseksi.

Taulukon 8 numeroiden valossa ovat parhaat tammat poikkeuksetta kohottaneet poikien vetotuloksia enemmän kuin kaikki tammat keskimäärin. Erot ovat vähäiset, mutta tämä on ollut odotettavissakin, koska 6 pisteen tammat ovat luultavasti vain verraten vähän keskitason yläpuolella olevaa tamma-ainesta. Vertailu keskituloksiin on kuitenkin osoittanut, kuinka välttämätöntä olisi saada parhaat oriit ja parhaat tammat keskenään siitokseen ja tähän tarvittava vetovoimaan perustuva luokittelu mahdollisimman oikeaksi ja tehokkaaksi.

\section{Loppupäätelmät.}

Oriiden vetovoiman periytymisen toteaminen edellyttää, että niin isien kuin poikienkin vetokokeissa saamat tulokset mahdollisimman tarkasti vastaavat niiden todellista vetovoimaa. Muiden vetovoiman ohella vetotuloksiin vaikuttavien tekijöiden, kuten esim. erilaisen valmennuksen, luonteen ja koeolosuhteiden erilaisuuden osuutta vetovoimaluokitukseen on sen vuoksi vetovoiman periytymistä tutkittaessa pyrittävä rajoittamaan. Tässä mielessä olisi jatkuvasti kiinnitettävä huomiota kantakirjaan tarjottavien oriiden työhön käytön ja kokeisiin valmentamisen tehostamiseen. Viimeksikuluneina vuosina tapahtunut vetotulosten kehitys onkin johtanut siihen, että kohonneet porrasluvut ilmeisesti entistä paremmin kuvastavat oriiden vetotaipumusta. Keskimääräisten vetotulosten jatkuva jyrkkä nousu osoittaa kuitenkin, että tulosten tarkkuuden lisäämiseen on vielä mahdollisuuksia. Edelläesitetyssä tutkimuksessa on kaikkien isä- ja poikaoriiden vetokykyjen vuorosuhteeksi saatu $+0.17 \pm 0,10$.

Luonteesta johtuvan häiriövaikutuksen vähentämiseksi on vetovoiman periytymistä selvitettäessä laskettu vuorosuhde myöskin aineistosta, josta on jätetty pois lähinnä huonon luonteen vuoksi alimpiin porrasluokkiin karsiutuneet oriit. Isä- ja poikaoriiden vetovoimien vuorosuhdetta osoittavaksi kertoimeksi on tällöin saatu $+0,29 \pm 0,10$. Vuorosuhteen suurentuminen osoittaa vetokyvyn tekijäin, luonteen ja vetovoiman, eroittamisen merkitystä vetovoiman periytymistä tutkittaessa, vaikkakaan se käytännöllisessä kantakirja-arvostelussa, jonka eräänä päämääränä on vain vetokyvyltään heikoimpien yksilöiden karsiminen siitoksesta, ei ole tarpeellista.

Eräänä lopputulokseen häiritsevästi vaikuttavana tekijänä on mainittava myöskin emien osuus poikaoriiden vetovoimaan. Koska tammojen vetokokeet nykyisellään karsivat vain kaikkein heikoimmat yksilöt, ovat kantakirjaan hyväksytytkin tammat vetovarmuudeltaan varsin heterogenista ainesta. Tässä tutkimuk- 
sessa on tammojen häiritsevää vaikutusta vetovoiman periytymisen toteamiseen pyritty vähentämään siten, että laskelmat on tehty myöskin vain ne poikaoriit käsittävästä aineistosta, joiden emien vetovarmuus on arvosteltu 6 pisteeksi. Isien ja poikien vetovoimien vuorosuhteeksi on tällöin saatu $+0,33 \pm 0,11$. Jos vuorosuhde lasketaan kunkin isän poikien keskimääräisten porraslukujen perusteella, jolloin jokainen isäori esiintyy vain kerran korrelatiotaulussa, tulee vuorosuhteen arvoksi $+0,46 \pm 0,15$. 6 pisteen tammatkin ovat tuotannolliselta laadultaan kuitenkin vielä perin epätasaista ainesta, minkä vuoksi tammojen kantakirjaarvostelussa olisi tarpeellista pyrkiä nykyistä täsmällisempään vetovoimaluokitteluun.

Jalostustyön onnistumisenkin kannalta olisi tammojen tehokkaampi vetovoimaluokittelu toivottavaa, koska, kuten kyseisen tutkimuksen tulokset osoittavat, vain parhaita yksilöitä keskenään siitokseen käyttäen saadaan keskitason selvästi ylittäviä jälkeläisiä. Siitosvalinnan ohjaamiseksi entistä enemmän ensisijassa vetovoiman kehittämiseen, olisi hyvän vetotuloksen merkitystä hevosen arvokkaimpana jalostuksellista ja taloudellista käyttöarvoa osoittavana arvosteluperusteena pyrittävä kaikin keinoin korostamaan. Myöskin tulisi kantakirjatarkastusten vetovaatimusten seurata sitä nopeata vetotulosten kehitystä, mikä on ollut viime vuosina yhä paremman vetokokeisiin valmentautumisen seurauksena.

Kokeiluolosuhteiden erilaisuudesta johtuvien virheiden vähentämiseksi oriiden kantakirja-arvostelussa olisi kevätnäyttelyistä ehkä syytä luopua. Myöskin mikäli kesä- ja syyskauden näyttelyissä kokeilurata on niin märkä, että auton pyörien liukuminen on mahdollista, olisi käytettävä lumiketjuja; samoin tulisi kengityksen kesälläkin olla sellainen, että jalkojen liukuminen ja lipsahtelu estyy. Edelleen olisi ratojen kunto kaikkialla saatava samalle ja mahdollisimman hyvälle tasolle.

Niinkuin jo aikaisemmin on mainittu, ei esitettyjä tutkimustuloksia voida toistaiseksi pienen tutkimuksiin kelvollisen aineiston vuoksi pitää lopullisina eikä niiden antamaa kuvaa tutkituista seikoista lähimainkaan oikeina, vaan voivat tulokset myöhemmin huomattavastikin muuttua. On kuitenkin mahdollista, että pyrittäessä esitettyjen virhemahdollisuuksien yhä tarkempaan rajoittamiseen, voidaan niin hevosen vetovoiman periytymisen selvittämisessä kuin sen kehittämisessäkin päästä nykyistä parempiin tuloksiin.

KIRJALLISUUSLUETTELO:

(1) Lonka, T., Hevosten vetokyvyn arvostelumahdollisuuksista. Summary: The Evaluation of the Pulling Ability of Horses. Valtion Maatalouskoetoiminnan Julkaisuja N:o 126. Helsinki 1946.

(2) Vainikainen, V., Suomalaisen hevosen jalostuksesta. Summary: Breeding the Finnish Horse. Suomen Maataloustieteellisen Seuran julkaisuja (Acta Agralia Fennica) 62. Helsinki 1946.

(3) VAro, M., Hevosen iän ja vetovoiman keskinäisestä suhteesta. Eripainos Koetoiminta ja Käytäntölehdestä. Helsinki 1947. 


\title{
SUMMARY.
}

\section{THE DEVELOPMENT OF THE FINNISH HORSES' PULLING POWER.}

\author{
MikKo VARo. \\ Ministry of Agriculture, Helsinki.
}

The development of the horses' pulling power by breeding is disturbed by many factors which render it difficult to substantiate. At the time of registration for, the pedigreebook, the pulling test done by the dynamometer does not present a right picture of every stallions pulling power, as all are not sufficiently well trained for the test. Also the experience of pulling is often slight owing to the lack of work, eventhough the war has improved the situation in this respect. Furthermore faults in caring for and feeding the horse may hinder producing the horses' full pulling propensity. Besides these different circumstances may effect the results of test performed at various times of the year. Especially the average level of the results in the spring show is erronecously high owing to the test car's tyres slipping on account of the wet ground.

The affect of all the above-mentioned inaccuracies can be lessened by using the experimental technique, and the great rise in the experimental results after 1940 is foremost to be put to the merit of the stallions being better accustomed to work, showing that the development has quickly led to even more dependable results. But even if all these experimental faults in technique could be removed the pulling ability of the stallion in the pulling test does still not show its tractive ability because it is the combincd results of power and character. The dividing of horses into stepgrades shows that the characteristically deficient horses weed out together with the inexperienced already in the exercise- or walking route or in the first steps. This is confirmed by the manner of weeding out, because horses belonging to the lower stepgrades are not able to start their pull at all; when insted strenght fails those which have reached the higher steps while on the traction stretch with their load. In investigating the inherited pulling power one has, therefore, taken into account from each age group only the stallions who have pulled at least $35 \%$ of their liveweight, as in this way one has been able to weed ont the lower stepgrades' characteristiccally deficient and untrained horses.

The correlation obtained from sires and sons by this procedure is $+0.29 \pm 0.10$. Now the mares' different pulling reliability was not at all taken into account. In order that the mares' dissimilar influence on results could be made the lowest possible, the correlation has also been calculated only from material comprising sons whose dams' pulling reliability has been valued at 6 points. The correlation then obtained is $+0.33 \pm 0.11$.

The final result is harmfully effected by the fact that the correlation is nearest dependent on the stallions who have plenty of offspring. Owing to this, the results have been calculated so that the average of each son has been reckoned and that the correlation between the sires' and sons' average. Thus one obtains in the whole material of the sires' and sons' correlation $+0.37 \pm 0.15$, and from the material comprising sons of 6 point dames $+0.46 \pm 0.15$.

The sons have been at an average 0.32 steps better than their sires, which foremost is due to them being better trained for the pull. In the pulling results of the sons one can however also notice the influence from the dams, because the sons of 6 point dams have at an average been 0.78 steps better than their sires, and the sons of 5 point dams exactly equal with their sires, and the sons of $0-4$ point dams 0.15 steps poorer than their sires.

The comparison of the average of all the stallions shows that the sons of the best stallions have most obviously exceeded the midlevel and from the point of view of development of pulling power the best results have been gained when more powerful stallions have been used in breeding with dams most reliable in pulling.

In order to gain even better results in the development of horses' pulling power, the excercising for test should be made even more effective than previously. To lessen the technical test faults the spring shows should be given up and even in summer when the ground is wet, the slipping of car tyres should be prevented by snow-chains. The testing of dams' pulling power should be developed similarly to that of the stallions. The pedigree book demands should follow the rapid progress which has been noticed in recent years in the pulling tests thanks to better training. 